\title{
Stanisław Kosowicz
}

\section{Ewolucja pojęcia celu małżeństwa}

Prawo Kanoniczne : kwartalnik prawno-historyczny 31/3-4, 131-140

1988

Artykuł został zdigitalizowany i opracowany do udostępnienia w internecie przez Muzeum Historii Polski w ramach prac podejmowanych na rzecz zapewnienia otwartego, powszechnego i trwałego dostępu do polskiego dorobku naukowego i kulturalnego. Artykuł jest umieszczony w kolekcji cyfrowej bazhum.muzhp.pl, gromadzącej zawartość polskich czasopism humanistycznych i społecznych.

Tekst jest udostępniony do wykorzystania w ramach dozwolonego użytku. 


\section{KS. STANISEAW KOSOWICZ}

\section{EWOLUCJA POJECTA CELU MAEZENSTWA}

Tresc: Wstęp. - 1. Ujęcie celu malżeństwa w KPK z 1917 r. -2 . Ewolucja nauk humanistycznych a cel małzeństwa. - 3. Magisterium Kościoła o celu małżeństwa. - Zakończenie.

\section{Wstęp}

Małżeństwo stanowi podstawową wspólnotę naturalną istniejąca na Ziemi od stworzenia pierwszych ludzi oraz podstawową komórkę społeczną, w której rodzi się i wychowuje człowiek. Rozwój osoby ludzkiej możliwy jest wylącznie we współdziałaniu z innymi osobami, w pierwszej kolejności z rodzicami. Właśnie z tych względów małżeństwo i rodzina we wszystkich społecznościach ludzkich traktowane są ze szczególną powagą.

Problematyką zarówno małżeństwa, jak i rodziny żywo zainteresowane są Państwo i Kościół. Ważność i wieloaspektowość tego zagadnienia sprawiły, że znalazło się ono $w$ centrum zainteresowania różnych nauk, w tym psychiatrii i psychologii. Zajmują się nim także nauki filozoficzne i teologiczne. Warto zatem ukazać ich wpływ na pełniejsze wyrażenie pojęcia celu małzeństwa od wydania w 1917 r. Kodeksu Prawa Kanonicznego do Soboru Watykańskiego II.

\section{Ujęcie celu małżeństwa w KPK $z 1917 x$.}

Dokumentem Kościola, który w sposób zdecydowany ustawia hierarchicznie cele małżeństwa, jest KPK z 1917 r. Prawodawca w kanonie 1013 \& 1 określa, że cel pierwszorzędny małżeństwa stanowi zrodzenie i wychowanie potomstwa, a drugorzędny - wzajemna pomoc i zaspolkojenie popędu. Nasuwa to konkluzję, że małżeństwo jako instytucja prawa publicznego ma służyć przede wszystkim celowi społecznemu.

Cel pierwszorzędny małżeństwa znajduje swoje uzasadnienie biblijne - w Księdze Rodzaju $(1,28)$ czytamy bowiem: „Bądźcie płodni i rozmnażajcie się, abyście zaludnili ziemię". Podobne treści spotykamy równiez w Listach Apostolskich 1. Papię Pius XI natomiast w encyklice Casti connubii, rozważając cel pierwoszędny, mówi: „Jak wielkim zaś dobrodziejstwem Bożym i błogosła-

\footnotetext{
1 Por. 1 Tm 2, 15; Tym 5, 14.
} 
wieństwem małżeństwa jest dziecko, okazuje się z godności człowieka i jego najwyższego celu (...) chce Bóg, aby ludzie rozmnazali się nie tylko po to, aby istnieli i zapełniali ziemię, ale przede wszystkim w tym celu, aby stawali się czcicielami Boga, aby Go poznawali i miłowali oraz aby przez całą wieczność cieszyli się Jego posiadaniem w niebie. Cel ten, wskutek przedziwnego wyniesienia czlowieka przez Boga do nadprzyrodzonego porządku, jest wyższy nad wszystko, co widziało oko czy słyszało ucho i co w ludzkie serce wstapilo (por. 1 Kor 2, 9). W blasku tych prawd jakże łatwo można zrozumieć, jak wielkim darem dobroci Bożej, jak doskonałym owocem małżeństwa jest dziecko, zawdzięczające swe istnienie Bożej wszechmocy i współdziałaniu małżonków" 2.

Cel pierwoszędny nie kończy się jednak na zrodzeniu potomstwa, lecz obejmuje również opieke i wychowanie ze strony rodziców, których obowiązkiem jest przygotowanie potomstwa do życia W społeczności 3. W kanonie 1013 Kodeksu Prawa Kanonicznego prawodawca rozwija obowiazzek realizowania celu pierwszorzędnego. Stwierdza, że na rodzicach ciąży obowiązek wychowania potomstwa zarówno pod względem religijnym i moralnym, jak i fizycznym, a także obywatelskim.

Ten sam kanon 1013 w paragrafie 1 jako cel drugorzędny makżeśstwa wymienia wzajemną pomoc i zaspokojenie popędu. Prawo katolickie nakłada na nowożeńców obowiązek niesienia sobie pomocy. Ponieważ małżenstwo jest sakramentem i ma być symbolem miłości Chrystusa do Kościoła, zatem relacje, jakie zachodzą między Chrystusem a Ludem Bożym, są wzorem, który mają realizować mężczyzna i kōbieta w stanie małżeńskim, a następnie rodzinnym, otwierając się na coraz szersze kręgi bliźnich. Miłość małżeńska, którą ślubują sobie narzeczeni podczas zawierania sakramentu małżeństwa, nie sprowadza się tylko do sfery seksualno-erotycznej, ale obejmuje całego człowieka. Cel drugorzędny, jakim jest również wzajemna pomoc, uwzględnia różnorakie potrzeby człowieka (psychiczne i fizyczne) w spełnianiu funkcji małżeńskich oraz w wypełnianiu obowiązków, jakie ciążą na małżonkach. Wśród podstawowych dla rozwoju człowieka potrzeb należy wymienić materialnè, intelektualne, kulturalne, religijne, potręebę poczucia bezpieczeństwa, przynależności, miłości, szacunku i samourzeczywistnienia. Wszystkie one kierunkuja sposób życia spoleczeństwa 4.

Pomoc świadczona sobie przez małżonków, która wynika z właściwie rozumianej milości, wyraża się we wzajemnej akceptacji mężczyzny i kobiety, szczególnie we wzajemnym uznaniu, zrozu-

1 P i us XI, Encyklika Casti connubii, AAS 22 (1930) 548 n.

- Z. Kozubski, Podstawy etyki píciowej, Poznań 1947, s. $45 \mathrm{n}$.

- J. L a s ow k i, Malzenstwo $i$ rodzina, Warszawa 1979, s. 31 . 
mieniu - także w przypadku choroby czy w starości - we wspólnej radości z macierzyństwa i ojcostwa, w uzgodnieniu postępowania odnośnie do wychowania dzieci.

$\mathrm{Na}$ marginesie warto zaznaczyć, że zagadnienia te znalazły ujęcie w jurysprudencji rotalnej okresu posoborowego, gdzie powyzsza treść sprowadza się do tzw. zdolności do relacji interpersojnalnych w małżeństwie ${ }^{5}$.

Wzajemna pomoc usposabia do głębszej i trwałej łączności $z$ Bogiem. Sprzyja pogłębieniu świadomości uzależnienia od Boga i działania Jego laski oraz lepszemu zrozumieniu tego, że malżeństwo i miłość są wielkim darem Boga i wspólną drogą do nieba. Najglębszy sens miłości małżeńskiej stanowi uwielbienie Boga przez slużenie zbawieniu i życiu ${ }^{6}$. Wzajemna pomoc, do jakiej zobowiązują się małżonkowie przyjmując sakrament małżeństwa, obejmuje wszystkie dziedziny życia ludzkiego, a więc naturalne i nadprzyrodzone, mające na względzie dobro calej osoby ludz-kiej, jej godność oraz dązność do doskonałości.

Wymienione tutaj przejawy wzajemnej pomocy małżonków sędziowie rotalni obejmują pojęciem bonum coniugum, wprowadzonym przez prawodawce do kanonu $1055 \S 1$ odnowionego Kodeksu Prawa Kanonicznego. Pojęcie to zostało wypracowane przez jurysprudencję rotalną okresu posoborowego w oparciu o dokumenty Soboru oraz dyskusje naukowców, w których poddawano krytyce hierarchiczne ustawienie celów małżeństwa. „Dobro małżonków", które wypływa z realizacji celów drugorzędnych, jest pojęciem szerszym niż treść mieszcząca się we wzajemnej pomocy oraz zaspokojeniu popędu?

Ostatnim celem; o którym wspomina Kodeks w kanonie 1013 $\S 1$, jest właśnie zaspokojenie popędu (remedium concupiscentiae). Wzajemny pociąg zmysłowy małżonków ma doniosłe znaczenie dla wypelnienia ich zadań rodzicielskich ${ }^{8}$.

Małżeńskie akty obejmują całego człowieka, jego sferę duchową i cielesną - mężczyzna i kobieta stają się ,jednym ciałem" 9 i mają prawo do intymnej miłości uświęconej przez Chrystusa. Miłość małżeńska sprawia, że każdy czyn i działanie kontrahentów nabierają wymiaru nadprzyrodzonego.

Ponieważ $w$ spełnianiu swoich powinności mężczyzna i kobieta powinni kierować się osiągnięciem wspólnego dobra (bonum co-

5 Por. decyzje Sacrae Romanae Rotae ( dec. SRR) z 15 VII 1977 r., coram (= s.) J. Pinto, Monitor Ecclesiasticus (= ME) 103 (1978) 147.

6 B. Härìg, Nauka Chrystusa, t. 3, Uczeń Chrystusowy $w$ matżeństwie, Poznań 1963, s. 279-282.

7 Por. dec. SRR z 12 III 1975, c. M a sa la, ME 101 (1976) 203 n.

B K. Wo j.t y ła, Mitość i odpowiedzialnośc, Kraków 1962, s. 175.

Por. Mt 19, 5. 
nugum), dlatego rozpatrując ujęcie celów małżeństwa przez Kodeks Prawa Kanonicznego z 1917 r. należy mieć na uwadze, że chodzi tu tylko o hierarchię prawną, w której dobro zbiorowe ma pierwszeństwo przed indywidualnym, a cele drugorzędne, podmiotowe - o charakterze indywidualnym - są wewnętrznie powiązane i podporządkowane celowi pierwszorzednemu, czyli dobru potomstwa 10. Od strony etycznej natomiast cel drugorzędny jest równie dobry jak pierwszorzędny i znajduje swoje uzasadnienie zarówno w Piśmie św. ${ }^{11}$, jak i naturze czlowieka ${ }^{12}$.

Już w kilkanaście lat po wydaniu KPK z 1917 r. nauka o celu małżeństwa ujęta w kanonie 1013 \& 1 spotkala się z zastrzezeniami teologów, moralistów i kanonistów. Zastanówmy się nad tym, co bylo przyczyną krytyki hierarchicznego ujęcia celu makzeństwa.

\section{Ewolucja nauk humanistycznych a cel malżeństwa}

Ostatnie dziesięciolecia przyniosły gwałtowny rozwój ludzkiej wiedzy i techniki, nastąpił nie spotykany wcześniej rozkwit nauk przyrodniczych, historycznych, humanistycznych i innych. Wiele $\mathrm{z}$ nich podejmuje $\mathrm{w}$ swych badaniach problematyke malzeństwa i rodziny, w tym na przykład historia, socjologia, psychologia, pedagogika, seksuologia, etyka, teologia, psychiatria itp. Teologia małżenstwa i rodziny wskazuje na rodzinę jako podstawowy ośrodek kultu i życia religijnego, szkołę apostolstwa i postawy chrześcijańskiej. Nawiazuje sie do Biblii i literatury patrystycznej, by lepiej wydobyć w problematyce małzeństwa wartości boskie i ludzkie.

Zwolennicy tradycyjnej nauki o celach małżństwa wywodzącej się od św. Tomasza uzasadniali nadrzędność rodzenia i wychowywania dzieci względem innych celów małżeństwa tym, że nakaz prokreacji zawarty w Piśmie świętym jest w pierwszym z dwóch tekstów glównych Księgi Podzaju, dotyczących małzeństwa: "Bądźcie płodni i rozmnażajcie się" (Rdz $1 ; 28)$.

Rozwój nauk historycznych i wynikająca $z$ niego lepsza znajomość poglądów i mentalności ludzi okresu patrystycznego oraz średniowiecza umożliwiły bardziej wszechstronne i krytyczne spojrzenie na poglądy ówczesnych autorów odnośnie do małżeństwa i. jego celu. Dla ludzi średniowiecza istotniejsze od osobistego było dobro wspólne, a w hierarchii dóbr wspólnych najważniejsze oka-

10 Por. S. Biskupski, Prawo matżeńskie Kościola rzymskokatolickiego, Warszawa 1959 , s. 44.

${ }_{11} \mathrm{Rdz} 2$. 18;2, 23-24; Mt 19,4-6; 1 Kor $7,2-3,9$.

12 Z. KOzubski, dz. cyt., s. 56.

13 A. Lanza, De fine primario matrimonii, Apollinaris 13 (1940) 218. 
zywało się dobro calej ludzkości, w jego zaś ramach na pierwszy plan wysuwało się utrzymanie istnienia społeczności ludzkiej. Niski poziom nauk medycznych i wysoka śmiertelność powodowały, że najważniejszą funkcją mał̇̇eństwa stawała się funkcja prokreacyjna: W świetle takiej mentalności rodzenie i wychowywanie potomstwa dominowało więc nad innymi celami małzenstwa 14.

Rozwój nauk biologicznych i medycznych w późniejszym okresie dostarczyl wiedzy o organizmie i psychofizjologii kobiety oraz mężczyzny. Wiemy dzięki temu, że czlowiek stanowi jedność psychofizyczną, a pleć jest nierozerwalnie związana $z$ cała osobowością. W oparciu o rozwój nauk medycznych moraliści zaczęli eksponować drugorzędny cel małzeństwa w ujęciu iradycyjnym 15 .

$\mathrm{Na}$ przestrzeni ostatnich 200-250 lat daje się obserwować wielość filozoficzno-etycznych ujęć malżeńskiej etyki seksualnej, przy czym, biorąc za podstawę orientację światopoglądową, można ową etykę podzielić na chrześcijańską i laicką. Wielki wplyw na nurt laicki wywarli pionierzy okresu oświecenia, a wśród nich między innymi J. J. Rousseau, który glosił, że milość erotyczna i życie płciowe znajdują najdogodniejsże warunki poza małżeństwen ${ }^{16}$.

Filozoficzne konfrontacje ze zwolennikami tzw. „wolnej miłości" stały się dla kanonistyki chrześcijańskiej okazją do pogłębienia doktryny o małżnśntwie i rodzinie. Zaczęto zwracać większą uwagę na rolę milości w tworzeniu wspólnoty małżenskiej i etyce mał́żeńskiej. Duży wpływ na wydobywanie właściwego znaczenia osoby ludzkiej i miłości osobọwej w malżeństwie wywarły poglądy powstale na gruncie personalizmu, fenomenologii i egzystencjalizmu chrześcijańskiego.

Charakterystyczne ujęcie miłości $w$ aspekcie personalistycznym daje kardynał $\mathrm{K}$. Wojtyła 17, wedlug którego mifość jest odniesieniem osób do siebie, zmierzającym do wspólnego ich dobra. Elementem istotnym wypływającym z miłości jest dobro zewnętrzne i wewnętrane osób ${ }^{18}$. Postawa personalistyczna powinna prowadzić do altruizmu, czyli pragnienia dobra drugiej osoby, do życzliwości, bezinteresowności ${ }^{19}$. Autor pisze, że miłość może przejawiác się jako sympatia, przyjaźń oraz milość oblubieńcza ${ }^{20}$, polegająca na oddaniu siebie samego osobie wybranej, co realizuje się w małżeństwie, gdzie milość kobiety i mężczyzny prowadzi do

${ }_{14}$ M. A. Cenovis, Le mariage selon le dessein de Dieu, Paris 1957 , s. 101.

15 B. H äring, dz, cyt., t. 5, s. 283.

${ }_{16}$ T. Slipko, Zycie plciowe czlowieka, Krakbw 1978, s. $26 \mathrm{n}$.

17 Por. K. W o jty $\mathrm{k}$, dz. cyt., s. $175 \mathrm{n}$.

18 Tamże, s. 62-68.

19 Tamie, s. 73-77.

20 Tamże, s. $77-80$. 
oddawania się sobie nawzajem, broniąc ich jednocześnie przed traktowaniem drugiego czlowieka jako przedmiotu użycia 21.

INa uwage zasługuje również egzystencjalna koncepcja miłości autorstwa G. Marcela, według którego miłość jest podstawową więzią interpersonalną, umożliwiającą jednostce współtworzenie swojego bytu osobowego 22. Inną koncepcję miłości, opartą na psychoanalizie, wysuwa E. Fromm ${ }^{23}$, który stwierdza, że milość jest formą działania, dawaniem siebie. Dar ten wzbogaca drugiego człowieka, wzmaga poczucie jego wartości 24.

Ponieważ milość tak przedstawiona przez myślicieli chrześcijańskich w specyficzny sposób realizuje się w małżeństwie i rodzinie, dlatego jest rzeczą zrozumiala, że zaczęto ją uznawać za istotny cel małżeństwa.

Osiągnięcia nauk medycznych i biologicznych oraz nowe spojrzenie filozofów na omawianą instytucje, jej nature i cel dały podstawę do weryfikacji tomistycznego schematu celów małzeństwa. Krytycy atakowali ciasnotę i jednostronność $\mathrm{w}$ podchodzeniu do prolemu małżeństwa, które jest przecież rzeczywistością bardzo złożoną, poddając krytyce schemat celów i podkreślając potrzebę dowartościowania miłości $w$ małżenstwie. Prawnicy i kanoniści włoscy nie uważali prokreacji za cel pierwszorzędny małżeństwa i określali ją jäko taki, ale wśród celów przypadłościowych. Kładli nacisk na duchowe zblizenie partnerów w małzeństwie $i$ to uważali za jego istotę 25 . W latach 30 -tych i 40 -tych naszego stulecia rozpoczęła się również polemika dotycząca moralnej oceny antykoncepcji 26.

Wynikiem toczących się na temat celów małżeństwa dyskusji są wypowiedzi papieży.

\section{Magisterium Kościola o celu malżeństwa}

W okresie gorących polemik dotyczących istoty małzeństwa zabrał głos Pius XI, wydając 31 grudnia 1930 r. encyklikę Casti connubii 27, gdzie podkreślił, że potomstwo stanowi pierwoszędny cel małżeństwa. Znajduje się jednak w tym dokumencie również sformułowanie mówiące, że wzajemne wewnętrzne kształtowanie

11 Tamże, s. 84-89.

*2 G. M a ree 1, Le mysterie de l'etre, II: Foi et realite, Paris 1951, S. 156 .

${ }_{23}$ E. Fromm, O sztuce mitosci, Warszawa 1971, s. $31 \mathrm{nn}$.

24 Tamże, s. $34-37$.

25 A. Pe i go, la nuova teorie sulla gerarchia dei fini matrimoniali, La civilità cattolica 110 (1969) 241.

${ }_{26}$ Por. J. Strojnow ski, Antykoncepcja, w: Encyklopedia katolicka, Lublin 1973, t. 1, kol. $718 \mathrm{n}$.

27 Pius XI, dz. cyt., 548. 
się małżonków, ̈̈ch wytrwały wysiłek skierowany na udoskonalenie się można nazwać primaria matrimonii causa et ratio ${ }^{28}$, czyli pierwszą racją i przyczyną małżeństwa. Encyklika ta nie rozstrzygnęła sporu dwóch stanowisk ujmujących istotę małzeństwa w aspekcie "dóbr". Pierwsze z nich, wyrażające się przede wszystkim w prawodawstwie kościelnym, uważalo za podstawowe dobro potomstwo, drugie natomiast - miłość.

Analiza encykliki Casti connubii rodzi pytanie: doskonalenie się małżonków czy potomstwo zajmuje pierwsze miejsce w małżenstwie? Próbowano tę trudność rozwiązać ${ }^{29}$, co bardziej potęgowało jeszcze dyskusje o małżeństwie, a zwłaszcza o jego celu.

W polemice lat 30 -tych ważne miejsce zajmuja prace $H$. Domsa i B. Krempla. Według pierwszego z nich małżeństwo jest wspólnotą miłości 30 , trwałym miłosnym związkiem dwóch seksualnie zróżnicowanych osób mającym na celu wzajemne udoskonalenie się i pomoc w niepodzielnej, nierozerwalnej wspólnocie życiowej. Dziecko stanowi cel wtórny, podporządkowany pierwszorzędnemu, którym jest właśnie doskonalenie się małżonków ${ }^{31}$. Doms uważal, że prokreacji i wychowania niemożna uznać za główny cel małżeństwa, a tylko za istotny element wewnętrzny wspólnoty małżeńskiej. Krytyce poddał również tezę św. Tomasza, który małeźństwo podporządkował dobru gatunku ${ }^{32}$. Autor postuluje nawet, aby w ogóle nie mówić o celach ,pierwszorzędnych” i „drugorzędnych" 33. Podobne stanowisko zajmował N. Rocholl uważający, że sensem małżeństwa jest pełna wspólnota życiowa małżonków ${ }^{34}$ a nie prokreacja.

Próby określenia celów małżeństwa podjął się również B. Krempel 35; według którego celem małżństwa jest związek płciowy, zjednoczenie dwojga osób różnej płci, dzieci natomiast stanowią naturalny owoc i najlepsze dobro tego związku. Wzajemnne doskonalenie się małżonków jest konsekwencją, końcowym rezultatem wspólnoty życia dwojga osób różnej płci. Rodzenie i wychowywanie potomstwa natomiast to jedna $z$ wartości życia małżeńskiego i razem $\mathrm{z}$ praca, zajęciami życia rodzinnego, życiem nad-

28 Tamże.

29 L. Janssens, Morale conjugale et progestogenes, Ephemerides: Theologicae Lovanienses 39 (1963) fasc. 4, p. 792 :

30 H. Doms, Vom Sinn und Zweck der Ehe, Breslau 1935, s. 99.

si Tamże, s. 100 .

32 Tamże, s. 39.

38 Tamże, s. 93 .

34 N. Rocho11, Die Ehe als geweihtes Leben, Dülmen i W. 1937, S. 82,88 .

ss B. Krempel, Die Zweckfrage der Ehe in neuer Beleuchtung. begriffen aus dem 'Wessen der beider Geschlechter im Lichte der Beziehungslehre des hl. Thomas, Eisideln 1941. 
przyrodzonym tworzą zespół wartości prowadzących do wzajemnego doskonalenia się malżonków ${ }^{\mathbf{3 6}}$.

Poglądy wymienionych autorów nie wpłynęły na oficjalną naukę Kościoła o małżeństwie, a Swięte Oficjum dekretem z 1 kwietnia 1944 r. określiło je jako teorię, „która nie może być przyjęta" 37. W dokumencie tym zostały odrzucone tezy przeczące temu. że zrodzenie i wychowanie potomstwa stanowią pierwszorzędny cel małeżństwa, a także twierdzące, że cele drugorzędne nie są istotewo podporządkowane pierwszorzędnemu, lecz równe mu i niezależne ${ }^{38}$. Papież Pius XII w swoich przemówieniach potwierdzał doktrynę małżeńską sformułowaną $w$ encyklice Casti connubii, a mówiąc o potomstwie jako celu pierwszorzędnym, podtrzymywal zdecydowanie naukę o hierarchicznym uporządkowaniu celów malżeństwa. Wypowiedzi Ojca świętego, nadające kierunek dyskusjom i prostujące niezbyt precyzyjne wypowiedzi autorów, opierały się na nauce św. Tomasza.

Także w innych wystąpieniach papiez Pius XII zabieral glos na temat celu małżeństwa. W dniu 3 października na przykład na otwarcie posiedzeń Trybunału Roty Rzymskiej w sprawach malżeńskich przypomnial tradycyjną naukę o celach małżeństwa ${ }^{39}$, a w przemówieniu do uczestników kongresu katolickich położnych w Rzymie w dniu 29 października 1951 r. ${ }^{40}$ przedstawił pozytywną naukę o celach małżeństwa. Papież stwierdzil, że nie zamierza odrzucać lub pomniejszać tego, co jest dobre i sluszne w wartościach osobowych wynikających $z$ małzeństwa i jego relacji, ale to wszystko nie może być oddzielone od pierwszorzędnej funkcji, czyli służby dla nowego życia. Całe wzbogacenie się osobiste, a także to, co jest najbardziej duchowe i głębokie w miłości małżeńskiej, z woli natury i Stwórcy oddane zostaje w shuzbę potomstwa 41. Zrodzenie i wychowanie potomstwa możliwe jest w warunkach głębszej wspólnoty opartej na szeroko pojętej wzajemnej pomocy ${ }^{42}$. Małżeństwo służy również dobru i szczęściu osobistemu kontrahentów, a wierność i całkowite wzajemne oddanie się małżonków sobie zabezpiecza to wspólne dobro.

W dokumentach Piusa XI i Piusa XII nie zostal dostatecznie podkreślony walor osobowy małżeństwa, niewystarczalność do-

${ }^{86}$ A. Ianza, Sui fini del matrimonio, La Scuola Cattolica 71 (1943) 159.

37 Dekret św. Oficjulm z 1 IV 1944 r., AAS 36 (1944) 103.

38 Por. A. B o s chi, Problemi morali del matrimonio, Torino 1953, s. 317.

39 Przemówienie Piusa XII z 3 X 1941 r., AAS 33 (1941) 423.

40 Pius XII, Etyka polożnej $i$ moralność życia matżeńskiego. Przemówienie do pielęgniarek i położnych z 29 X 1951 r., Jasna Góra 1958.

41 Tamże, s. 24.

42 Por. R. Carpentier, Les fins du mariage, Nouvelle Revue Theologique 67 (1945) 841 . 
tychczasowych jego ujęć była nadal powodem poszukiwań, dyskusji i krytyki. Niektórzy autorzy opowiadali się przede wszystkim za dowartościowaniem psychologiczno-personalistycznej strony małżeństwa, inni natomiast atakowali filozoficzne terminy - „cel pierwszorzędny" i ,cel drugorzędny".

Przedstawiona doktryna była oficjalnym stanowiskiem reprezentowanym przez Kościół aż do Soboru Watykańskiego II, gdyż zarysowujące się już wcześniej tendencje do zmiany ujęcia celu malżeństwa znalazły oddźwięk w dokumentach soborowych. Konstytucja duszpasterska Gaudium et spes, poruszając problem małżeństwa i rodziny, nawiązuje do aspektu psychologiczno-personalistycznego zagadnienia. Czytamy w niej: „Głęboka wspólnota życia i miłości małżeńskiej, ustanowiona przez Stwórcę i unormowana Jego prawami, zawiązuje się przez przymierze małżeńskie. czyli nieodwolalną osobista zgode" ( $\mathrm{nr} 48$ ).

Podobnie głębsze spojrzenie na małżeństwo w świetle filozofii i teologii znajdujemy u papieża Jana Pawła II ${ }^{43}$. Osiągnięcia nauk antroplologicznych doprowadziły do wyeliminowania pojęć „cel" pierwszorzędny" i „cel drugorzędny”. Ojciec św. - w oparciu o teksty skrypturystyczne - za cel najwyższy i ostateczny uznał zbawienie człowieka, do którego ma on zmierzać, wypełniając obowiązki związane ze swoim stanem - w tym wypadku małżeńskim. Kontrahenci, tworząc ze sobą wspólnotę calego życia, maja przez zrodzenie i wychowanie potomstwa osiagnnąć bonum coniugum (kan. 1055 \& 1 KPK z 1983 r.).

Odnowiony Kodeks Prawa Kanonicznego, promulgowany przez papieża Jana Pawła II, potwierdza, że małżeństwo należy ujmować przede wszystkim $\mathrm{w}$ aspekcie biblijnym (jako przymierze) oraz personalistycznym. Takie stanowisko jest wynikiem toczących się $w$ okresic międzykodeksowym dyskusji oraz rozwoju nauk medycznych i biologicznych. Obecny Kodeks Prawa Kanonicznego nie zawiera już rozróżnienia celów, ale podkreśla znaczenie bonum coniugum, pojmowanego bardzo szeroko - w aspekcie fizycznym, psychicznym oraz eschatologicznym.

Takie ujęcie małżeństwa zakończyło - jak należy sądzić burzliwe dyskusje okresu międzykodeksowego.

\section{Zakończenie}

Przedstawione $\mathrm{w}$ artykule przyczyny, które wpłynęły $\mathrm{w}$ okresie międzykodeksowym na głębsze zrozumienie celu małżeństwa, zasługują na uwagę. Jak wspomniano, zarówno dokumenty Soboru Watykańskiego II. jak i odnowiony Kodeks Prawa Kanonicznego

43 Jan P a weł II, Mężzyznq i niewiasta stworzył ich, Rzym 1986 s. $33 \mathrm{nn}$. 
wymownie świadczą o tym, że w oficjalnej nauce Kościoła zostały uwzględnione głosy naukowców wypowiadających się w tej kwestii. Prawodawca, odstępując od tradycyjnego hierarchicznego ustawienia celów małżeństwa i traktując zagadnienie tak szeroko, chciał zwrócić uwage na jego ważkość.

Określenie celów małżeństwa wydaje się być nieosiągalne, poniewaz filozoficzne terminy finis primarius i finis secundarius są w odniesieniu do małżeństwa sztuczne i niedokładne. Samo małżeństwo należy przecież rozpatrywać w wielu aspektach, stąd też niewątpliwa trudność w ujmowaniu tej instytucji wyżej wspomnianymi terminami.

Należy wspomnieć, że jurysprudencja rotalna $w$ najnowszych wyrokach, ukazujących się w czasopismach naukowych, unika w części in iure pojęć ,cel pierwszorzędny" i ,cel drugorzędny" małżeństwa, a sędziowie rotalni posługują się definicjami zaczerpniętymi $z$ dokumentów soborowych, nazywając małżenstwo wspólnotą życia i miłości, ukierunkowaną na bonum coniugum.

\section{The evolution of the conception of the matrimony}

In the period between of old and new Codes the Canonical Law it followed the censure included in the $1013 \S 1$ Code Law of 1917 year.

The development of the anthropological sciences contributed to call attention to man as the being sensual and spiritual:

The thinkers upon the basis of the attainment of the study of mental diseases, psychology, phenomenology began to grasp the person from the psichological - personalical side. It produced the critique of the definition of the aim the marriage included in the Code. It reproached, the expression "the firstrate aim" - "the second-rate aim" are artificial and inacurate with reference to the marriage. The Popes standing up voice in theis question did support the learning in the Code.

However the critique of these concepts conducted in the consequence, John Paul The Second promulgating the new Code Canonical Law of 1983 year hat not used these terms to determine the aim of the marriage. 